\title{
Institutional logics and social enterprises: entry mode choices of foreign hospitals in China
}

Article

Accepted Version

Creative Commons: Attribution-Noncommercial-No Derivative Works 4.0

Xing, Y., Liu, Y. and Lattemann, C. (2020) Institutional logics and social enterprises: entry mode choices of foreign hospitals in China. Journal of World Business, 55 (5). 100974. ISSN 1090-9516 doi: https://doi.org/10.1016/j.jwb.2018.11.004 Available at https://centaur.reading.ac.uk/81585/

It is advisable to refer to the publisher's version if you intend to cite from the work. See Guidance on citing.

To link to this article DOI: http://dx.doi.org/10.1016/j.jwb.2018.11.004

Publisher: Elsevier

All outputs in CentAUR are protected by Intellectual Property Rights law, including copyright law. Copyright and IPR is retained by the creators or other copyright holders. Terms and conditions for use of this material are defined in the End User Agreement.

$\underline{\text { www.reading.ac.uk/centaur }}$

\section{CentAUR}


Central Archive at the University of Reading

Reading's research outputs online 


\title{
Institutional logics and social enterprises: entry mode choices of foreign hospitals in China
}

\begin{abstract}
When social enterprises, being defined by their social mission and profitability, internationalize, they need to respond to institutional logics in the host country. By juxtaposing institutional logic and entry mode choice literature, this paper shows how social enterprises accommodate different institutional logics when they enter foreign markets. We collected data on Chinese healthcare reform, governmental policies and their changes, and conducted 36 in-depth interviews and three expert group meetings. By analyzing five nonChinese hospitals entering China, we show how social enterprises, as hybrid organizations, respond to governmental, commercial, and social institutional logics, when entering a foreign market.
\end{abstract}

Keywords: social enterprise; institutional logic; entry mode; foreign hospital; China; hybrid organization 


\section{Introduction}

Scholars, practitioners, and policymakers around the world have devoted vibrant and extensive attention to social enterprises (Battilana \& Lee, 2014; Nyssens, 2006; United Nations, 2015). Social enterprises have the mission and potential to bring positive change for individuals, organizations, and societies at large (Stephan, Patterson, Kelly, \& Mair, 2016). Although the extant literature on social enterprises articulates their importance in creating and measuring social value (Chmelik, Musteen, \& Ahsan, 2016), the research on their internationalization remains at a nascent stage (Yang \& Wu, 2015), placing its focus particularly on international social ventures and social entrepreneurship (Choi \& Majumdar, 2014; Mair \& Marti, 2006). Thus, an important theoretical gap remains in the understanding of the internationalization of social enterprises, especially concerning entry mode choices. In this article, we close this research gap by referring to international business research (Ahsan \& Musteen, 2011; Meyer, 2001), by analyzing five case studies, by reviewing documents on governmental policies and their changes, and by conducting 36 in-depth interviews and three expert group panels.

Given the organizational hybridity (Battilana \& Lee, 2014) involved in combining and accommodating different institutional logics-namely, commercial and social ones-the institutional logics perspective has been used to understand social enterprises (Mair, Mayer, \& Lutz, 2015; Pache \& Santos, 2013). Institutional logics are overarching sets of principles that prescribe "how to interpret organisational reality, what constitutes appropriate behavior, and how to succeed" (Thornton, 2004, p. 70). The complexity arising from the multiple and sometimes competing institutional demands placed upon organizations requires them to come up with appropriate responses (Greenwood, Raynard, Kodeih, Micelotta, \& Lounsbury, 2011; Thornton, 2004). For instance, the existing research found that individuals who operate in 
social enterprises use selective coupling to navigate among the competing demands involved in responding to competing institutional logics (Pache \& Santos, 2013).

Commercial and social logics of social enterprises tend to hold across geographical boundaries; however, governments may possess different institutional purposes and considerations, which can significantly affect organizational responses and performance outcomes (Liu, 2017; Stephan, Uhlaner, \& Stride, 2015). In an international context, a significant gap in social enterprise and hybrid organization research exists. Questions are still unanswered, such as: "How will institutional logics in a host country affect hybrid organizations when they enter the host country?" and "How would additional institutional logics, such as the governmental logic, influence the internationalization of social enterprises, beyond the commercial and social logics?". Until now, the existing research has failed to articulate why and how institutions affect the internationalization of social enterprises. To address this theoretical gap, we refer to the recent phenomenon of non-Chinese hospitals entering the Chinese healthcare sector (China Daily, 2017; Lin \& Tsai, 2010). As foreign hospitals in China are particularly focussed on providing patients with high quality care (Weill Cornell Medicine, 2017), we define them as social enterprises that need to manage tensions stemming from their hybrid characteristics. Hence, foreign hospitals in China follow a dual mission of generating profits (commercial logic) and creating social value (social $\operatorname{logic})$.

To generate social value, social enterprises often need to inherently reflect the interests of multiple stakeholders, such as customers, employees, businesses (Smith, Gonin, \& Besharov, 2013), and public sector agencies (Helmig, Spraul, \& Ingenhoff, 2016). Hence, they generally need to adopt a highly collaborative business mode. In contrast, we can observe that since China joined the World Trade Organization in 2001, for-profit multinational enterprises prefer wholly owned foreign subsidiaries over collaborative entry modes when entering 
China. In addition, since the Chinese government relaxed its regulatory framework from 2008 onwards, there has been a tendency for the international joint ventures already established in China to be converted into wholly owned foreign subsidiaries (Puck, Holtbrügge, \& Mohr, 2009). Thus, the question arises whether social enterprises in the healthcare sector follow the general business logic adopted by multinational enterprises (MNEs) — i.e. establishing wholly foreign owned subsidiaries — or the social, multi-stakeholder logic of choosing collaborative entry modes. Hence, our research questions are as follows: (1) Do hospitals - defined as hybrid organizing social enterprises-respond to institutional logics when they enter China as part of their internationalization processes? (2) If so, how do such hospitals respond to institutional logics?

In this paper, we juxtapose the theoretical lenses of institutional logics and the entry mode choice literature to generate revealing insights suited to close the outlined research gap, to answer our research questions, and to advance our understanding of the internationalization of social enterprises in general, and of foreign hospitals in China in particular. This study makes three important theoretical contributions to the research on the internationalization of social enterprises. First, it contributes to a nuanced and contextualized understanding of social enterprises by articulating collaborative partnerships as an entry mode choice for foreign hospitals that is suited to Chinese institutional dynamics. Second, our findings highlight the mechanisms deployed by foreign hospitals in responding to institutional logics—namely, organizing hybridity dynamically and utilizing collaborative partnerships. Third, our study highlights the role played by the government and its interaction with its healthcare service delivery partners — in the form of collaborative partnerships — in fostering healthcare system reform while, at the same time, creating social value.

This paper is organized as follows. We first review the conceptual background on social enterprises, institutional logics, and entry modes, and how these modes relate to the 
internationalization of social enterprises. We then present our research methodology and results. We conclude by discussing the implications for theory and managerial practice, and suggest future research directions.

\section{Literature review}

Social enterprises, hybrid organizations, and institutional logics

Social enterprises are often associated with both social welfare and commercial logics at their cores (Battilana \& Lee, 2014), and thus can be defined as hybrid organizations. Hybrid organizing is defined as "the activities, structures, processes, and meanings by which organizations make sense of and combine aspects of multiple organizational forms" (Battilana \& Lee, 2014, p. 397). By following competing goals (i.e. social and commercial), internal and external tensions for hybrid organizations may occur. Previous research has explored how hybrid organizations, especially social enterprises, can manage these tensions successfully. For instance, to gain legitimacy and acceptance, social enterprises selectively couple elements prescribed by either social welfare or commercial logics (Pache \& Santos, 2013). Further, to assign responsibilities for social and economic activities, social enterprises assign varying "spaces of negotiation" to distinct groups by creating areas of interaction in their organization designed to allow negotiation in the context of social enterprises (Battilana, Sengul, Pache, \& Model, 2015).

Social enterprises tend to start with a social mission to solve a social problem and may eventually turn to commercial activities to support their social mission (Zahra, Gedajlovic, Neubaum, \& Shulman, 2009), such as microfinance (Cobb, Wry, \& Zhao, 2016). However, as hybrid organizations, social enterprises need to combine both the commercial and social goals at their cores. The blended value promised by hybrid organizations may remedy the negative effects of entrepreneurial capitalism (McMullen \& Bergman Jr, 2017; McMullen \& 
Warnick, 2016). Arguably, the social role of entrepreneurship can have an impact on the pursuit of blended value at the organizational level, centering on balancing the creation of financial, social, and environmental wealth (Zahra \& Wright, 2016). Therefore, to gain an enhanced understanding of social enterprises, it is important to take note of the literature stream on institutional complexity, the phenomenon that arises when organizations are faced with multiple and competing institutional logics (Greenwood et al., 2011).

Institutional logics are overarching sets of principles that prescribe the ways in which organizational reality, the expected appropriate behaviors, and the pathways for organizations to succeed in institutional settings are to be interpreted (Friedland \& Alford, 1991; Thornton, Ocasio, \& Lounsbury, 2012). Thus, individuals and organizations are required to deploy appropriate responses when dealing with institutional complexity. Institutional logics coexisting within an organization are likely to differ depending on whether these logics are core or peripheral to the organization, as well as on the extent to which they provide compatible prescriptions for action (Besharov \& Smith, 2014). Mair et al. (2015) identified two forms of hybrid organizing: "conforming hybrids", which rely on the prioritization of a single institutional logic, and "dissenting hybrids", which use selective coupling to combine and balance the prescriptions of several institutional logics. One recent study demonstrates that structured flexibility, consisting of the interaction of stable organizational features and adaptive enactment processes, can sustain organizational hybridity over time for social enterprises (Smith \& Besharov, 2017).

In healthcare management, prior studies highlight the prevailing influence of institutional logics, and the co-existence of multiple logics can simultaneously affect organizations (Reay \& Hinings, 2005). Furthermore, rivalry between competing logics can be managed through the development of collaborative relationships (Reay \& Hinings, 2009). In addition, the coexistence of care and science logics jointly influence the development of medical education 
and the preparation of professionals in the healthcare sector (Dunn \& Jones, 2010). However, the extant studies mainly consider commercial and social logics as competing logics in the case of hybrid organizations. Only a few studies have begun to look at institutional complexity in a more nuanced manner. For instance, one study on Danish healthcare centers found that local actors' choices were influenced by their relationships with an external institutional context - in this case, local political parties adopted a national party ideology, whereas professionals chose a professional ideology (Waldorff \& Greenwood, 2011). Recent research has begun to highlight the dynamic feature of institutional logics in affecting healthcare professionals. One study demonstrates that changes in institutional logics can even change the identities of professionals in the healthcare system from "narrow specialism" in primary care, which characterized the Soviet health system, to "generalism", which characterizes primary care in the West (Kyratsis, Atun, Phillips, Tracey, \& George, 2017).

In the context of transition and emerging economies, institutions have a higher propensity to be changed and transformed in a rapid manner, generating important implications for organizations and international business practices (Meyer \& Peng, 2016). However, one significant research question still remains unanswered: "How do hospitals-understood as social enterprises-respond to institutional logics when they enter a different country?" Commercial and social logics, which are the core for social enterprises, may hold across geographical boundaries, but governments possess different institutional purposes and considerations. As such, our paper aims to fill this important gap by looking at the influence of additional institutional logic, such as governmental logic, beyond the commercial and social logics that form the core of social enterprises as hybrid organizations.

\section{The entry mode choices and internationalization of social enterprises}

International entry mode choices are a prominent topic in international business research (Ahsan \& Musteen, 2011; Brouthers \& Hennart, 2007). Research shows that a number of 
factors influence entry mode choices, including national cultures (Kogut \& Singh, 1988), global strategic considerations (Kim \& Hwang, 1992), ownership structures (Musteen, Datta, \& Herrmann, 2009), institutional and human resource distances (Estrin, Baghdasaryan, \& Meyer, 2009), and resources (Meyer, Estrin, Bhaumik, \& Peng, 2009). Emerging markets can differ from developed markets in most significant dimensions-institutional, economic, cultural, social, and technological (Meyer \& Peng, 2016). The institutional environments in developed markets can differ significantly from those of emerging ones; this difference can affect corporate strategies and business operations (Hoskisson, Wright, Filatotchev, \& Peng, 2013; Meyer, Mudambi, \& Narula, 2011). For instance, emerging market multinationals possess a relatively lower power status compared to their foreign counterparts in their internationalization endeavors (Liu \& Meyer, 2018). Thus, Chinese enterprises' learning behaviors and interactions with upstream foreign direct investment (FDI) can be conducive to enhancing their export quality (Majchrzak, Griffith, Reetz, \& Alexy, 2018). Hence, we argue that the institutions of emerging economies deserve salient consideration in relation to entry mode choices.

Collaborative partnerships are an important organizational form in international management, influencing entry modes, inter-organizational relationships (Lumineau \& Oliveira, 2018), mergers and acquisitions (Liu, Öberg, Tarba, \& Xing, 2018), and joint ventures (Beamish \& Lupton, 2009; Lyles \& Salk, 1996). The institutional logics that exist between collaborating partners affect organizational behaviors and performance outcomes. For instance, they can influence innovation in young firms (Pahnke, Katila, \& Eisenhardt, 2015). Furthermore, the logics brought by partners may be competing, subsequently influencing organizational behaviors. Almandoz (2014) shows how the institutional logics of bank founders-namely, financial and community logics—can influence the degree of risk taking in their 
organizations. In a similar vein, when collaborating with Chinese partners, foreign hospitals may bring different logics, thus affecting strategic and organizational operations.

The existing research on the internationalization of social enterprises is in its nascent stages (Yang \& $\mathrm{Wu}, 2015$ ) and is primarily focussed upon international social venture and entrepreneurship (Chmelik et al., 2016; Roundy \& Bonnal, 2017). Our research stream is closely linked to international social entrepreneurship (Choi \& Majumdar, 2014; Mair \& Marti, 2006; Stephan et al., 2016) and to research on operational modes and expansion strategies in the internationalization processes of social enterprises (Yang \& Wu, 2015). Studies on international social entrepreneurship have also articulated the important role played by institutions in highlighting institutional voids, institutional support, and institutional configurations (Estrin, Mickiewicz, \& Stephan, 2016; Stephan et al., 2015).

In emerging economies, social entrepreneurship needs to deploy appropriate strategies to deal with institutional constraints or weak regulatory or political support (Janssen, Fayolle, \& Wuilaume, 2018), such as BRICS countries (Littlewood \& Holt, 2018; Sengupta, Sahay, \& Croce, 2017). Within this research stream, the creation of social value (André, Cho, \& Laine, 2017) plays an important role in the strategic and operational implementations of social enterprises in the context of internationalization. The emphasis on social value and social consequences in an international context is also found in research on MNEs' social responsibility in emerging economies (Lattemann, Fetscherin, Alon, Li, \& Schneider, 2009; Li, Fetscherin, Alon, Lattemann, \& Yeh, 2010).

Inter-organizational relationships constitute one key dimension of hybrid organization (Battilana \& Lee, 2014). Social enterprises entering into partnerships need to combine forms through external relationships, such as financial capital providers (Wry, Lounsbury, \& Jennings, 2014) and outsourcing partners (Ebrahim, Battilana, \& Mair, 2014). However, there 
exists the danger of mission drift for social enterprises, if the inter-organizational relationships for hybrid organizations are not well managed (Santos, Pache, \& Birkholz, 2015). The core challenges for social enterprises center on how to design and implement an appropriate organizational form and inter-organizational relationships that may contribute to developing, governing, and sustaining their undertakings. Thus, the core question for internationalization of social enterprises is how they can formulate and manage the collaborative international partnerships while in the process of their internationalization endeavours.

\section{Research method}

\section{Research context}

The healthcare sector constitutes an important research setting for international management and organization studies. Research has been conducted within the healthcare sector in respect to organizational change (Battilana \& Casciaro, 2012; Reay, Golden-Biddle, \& Germann, 2006), leadership (Battilana, Gilmartin, Sengul, Pache, \& Alexander, 2010; White, Currie, \& Lockett, 2014), and healthcare professionals (Kyratsis et al., 2017). However, the extant research has primarily focussed upon Western contexts (Nigam \& Ocasio, 2010; Reay \& Hinings, 2005). Research on healthcare in China, however, is scant, especially given the fact that China has the largest population in the world and faces challenges linked to an aging population (Kulik, Ryan, Harper, \& George, 2014) while undergoing a significant health system reform (Lou, Li, Yin, Kim, \& Chan, 2016). Hence, we argue that investigating the Chinese healthcare sector, especially hospitals and the health system reform, can be justified (Eggleston, 2012; Freeman III \& Boynton, 2011).

In this study, hospitals can be understood as hybrid organizations, because they need to combine both social and commercial logics. On the one hand, the social logic is reflected in 
their social mission to cure illness, take care of patients, and achieve the betterment for the human being by educating and preparing professionals (Dunn \& Jones, 2010). On the other hand, the commercial logic is represented by the goal of remaining viable as an organization that is able to deliver its social mission. The need for a health system reform is a pressing societal and economic challenge in China as the country is faced with a slowing growth, an aging population, a surge in non-communicable diseases, and rising healthcare costs (Islam, 2016). Thus, any solutions suited to tackle the Chinese healthcare challenges not only require clear and careful research guidance but also necessitate collaborative approaches to goalsetting, planning, and strategizing across a broad base of relevant actors, organizations, and policymakers, while at the same time drawing upon international experiences (George, Howard-Grenville, Joshi, \& Tihanyi, 2016).

Despite the constant investment in medical resources, especially in large high quality hospitals, seeing a doctor in China remains extremely difficult, with long waiting times and high healthcare costs in large hospitals. The current Chinese hospital-centric model needs deeper reform to shift to a more patient-centric one-one that focusses on health outcomes and equitable access - as recommended by the World Bank's joint report with the Chinese government and the World Health Organization (Lou et al., 2016; Süssmuth-Dyckerhoff \& Then, 2017). Furthermore, the Chinese government has adopted an evolving and dynamic approach toward foreign hospitals, foreign doctors, and the healthcare sector. For instance, the pharmaceutical industry has experienced several mergers and acquisitions (Barbieri, Huang, Pi, \& Tassinari, 2017), and policy has an important bearing on FDI localization in China (Li, Angelino, Yin, \& Spigarelli, 2017). According to the 2015 China Health and Family Planning Statistics Yearbook (2015 中国卫生和计划生育统计年鉴) ${ }^{1}$, by the end of 2014, there were over 200 hospitals and health service providers that involved foreign

\footnotetext{
${ }^{1}$ http://www.nhfpc.gov.cn/zwgkzt/tjnj/list.shtml
} 
investment in China, of which 55\% were clinics, $30 \%$ were comprehensive hospitals, and 15\% were specialized hospitals. Thus, a nuanced understanding of the entry mode of foreign hospitals and how they respond to the institutional environment in China is needed.

\section{Qualitative research method}

To answer our research questions, we adopted a qualitative research method (Eisenhardt, 1989; Eisenhardt \& Graebner, 2007; Yin, 2009). Our choice of method is justified by three main reasons. First, the research on the internationalization of social enterprises is arguably in its nascent stages (Chmelik et al., 2016), which has resulted in a wide range of definitions and phenomena, some of which are overlapping or even contradictory. Hence, qualitative research may facilitate clarification while contributing to theory building. Research shows that the qualitative method is conducive to capturing the core of our research, i.e. institutional logics (Reay \& Jones, 2016). Second, in conducting qualitative research we embrace the notion of pluralism (Cornelissen, 2017). We suggest that the adoption of qualitative research methods may help to advance theoretical development, especially when the theoretical concepts, such as the internationalization of social enterprises, are still in their nascent stages. Combining case studies with a storytelling method (Xing \& Liu, 2015; Xing \& Starik, 2017) may capture the nuances and complexities of social enterprises in different international contexts. Third, a qualitative method can be an important research technique, offering additional insights in tackling societal and economic challenges in international management (Liu \& Vrontis, 2017; Liu \& Meyer, 2018).

\section{Data collection and analysis}

Our data collection consisted of two phases. During the first, we collected our data through a governmental policy consultation project-which ran from September 2014 to December 2015 - on the issues found in the Beijing area healthcare reform and development. In this phase, our research was aimed at obtaining a nuanced understanding and an updated 
overview of the Beijing healthcare reform issues from a broader perspective, including healthcare policy changes, health service providers, pharmaceuticals, and traditional Chinese medicine. A discussion of the role played by foreign hospitals was included.

In the second phase, our data collection placed a special focus on the characteristics and conditions found in foreign hospitals and on the influence of the Chinese government's policies and regulatory environment pertaining to the entry mode of foreign hospitals. This stage of the data collection took place between November 2017 and January 2018. Our primary data were collected through in-depth interviews with medical doctors, department directors, hospital heads, medical service doctors, healthcare associations, and health policy authorities. In total, 36 in-depth interviews and three expert panels were conducted. Table 1 provides an overview of the interviewees in our sample, and of their roles and positions in various healthcare-related organizations.

--- Insert Table 1 about here ---

Our choice of case studies followed the theoretical sampling technique. We purposefully selected five foreign hospitals in China based upon three criteria. First, we chose foreign hospitals that had been founded at different points of time, to cover a wide spectrum from early phases to modern development in China's healthcare environment. This longitudinal and historical perspective provides us with the opportunity to observe the influences of institutional dynamics and regulatory frameworks on the internationalization of foreign hospitals. Second, our sample needed to contain two different types of foreign hospital ownership structures-namely, wholly foreign-owned and collaborative partnerships. This comparative perspective provided the background to contrast and discern the differences and commonalities experienced by foreign hospitals in relation to their adoption of different entry 
modes into China. Third, the foreign hospital founding investors had to come from different countries, including highly advanced foreign investors from the USA, and neighbourhood investors from the regions of Taiwan and Hong Kong. By following these criteria, we obtained a balanced sample suited to provide revealing insights into the distinctive characteristics of foreign hospitals stemming from different health systems and into their influences on the Chinese health system reform. Table 2 provides an overview of the five cases along different dimensions. We also used archive data drawn from publicly available sources to triangulate the primary data, especially with regard to the health policy development and changes. By following the time-based process approach (Chandra, 2017), we trace the policy development longitudinally and situate our cases along the developmental trajectory of health policy in China, which helps to explicate the entry mode choice of foreign hospitals over time.

--- Insert Table 2 about here ---

\section{Findings}

The governmental logic and regulatory changes in relation to foreign hospitals

Our analysis points at governmental logic as a salient institutional logic for foreign hospitals in China, especially in terms of the dynamics and evolving nature of regulatory changes. In this sense, foreign hospitals, understood as hybrid organizations, not only combine commercial and social logics, but also need to respond to governmental logic when they enter the Chinese healthcare sector. The evolution of the Chinese government's view of foreign hospitals is characterised by three periods; namely, the early (1989-2000), development (2001-2013), and transformation (2014-2017) phases. The Chinese healthcare system reform was driven by the government to tackle societal and economic challenges. 
In the early phase, the Chinese healthcare system was dominated by a hospital-centric model (Lou et al., 2016). In contrast to the healthcare service delivery model found in other advanced economies, such as the UK or Germany, China lacked a tiered healthcare system, which resulted in long waiting times and high medical costs. Patients were inclined to visit large hospitals irrespective of their levels of illness (Süssmuth-Dyckerhoff \& Then, 2017). The concentration of healthcare resources in large public hospitals could not accommodate the increasing demand for quality healthcare services. A governmental official in the healthcare administration explained,

It is both expensive and difficult to see doctors (看病贵, 看病难) because almost all patients flock to hospitals. Irrespective of the kinds and degrees of their illnesses, such as a cough or a cold, patients still go to large hospitals. This has put too much burden to large hospitals, although the government has provided them with many resources. There is the urgent need for healthcare reform! (Deputy director at Beijing Municipal Health Bureau)

Foreign hospitals may take advantage of the opportunities stemming from the Chinese healthcare system reform to enter into the Chinese healthcare sector. One hospital manager expressed that:

There is a need for foreign hospitals in China, given the size of China's population and the huge demand for quality healthcare services. Ensuring equitable healthcare service delivery is at the top of the government agenda. Also, the Chinese government wants to achieve both social welfare through equitable access, and efficiency facilitated by market competition. Opening up the healthcare sector can force Chinese hospitals to reform, improve, and compete. (Case E, department director) 
The involvement of private organizations, including foreign hospitals, in the Chinese healthcare system may contribute to a reduction of the financial burden on public resources. In this respect, our findings support the previous research that found that the private healthcare sector in Myanmar helped to increase the quality of healthcare services, while partly protecting the public healthcare system from high expenditure (Lönnroth, Aung, Maung, Kluge, \& Uplekar, 2007). Importantly, the Chinese government is keen to mobilize and leverage resources to address public management issues by encouraging private participation, such as the use of public-private partnerships in fostering regional entrepreneurship in China (Xing, Liu, \& Cooper, 2018).

In the case of healthcare service delivery, the gradual opening of the healthcare market in China through a series of policy documents and regulatory changes can be observed. However, the dynamics of regulatory changes have required foreign hospitals in China to come up with agile responses in dealing with institutional logics. A foreign hospital manager concluded:

The policy environment is evolving, changing, and is sometimes unpredictable. There was a time when foreign hospitals had been removed from the restricted list of FDI in China. That triggered several initiatives aimed at establishing wholly foreign-owned hospitals. However, you must understand the institutions and government policies, both from central ministries and local government. You need the flexibility and capacity to respond to the policies. (Case D, HR manager)

This illustrates how the regulatory frameworks tend to constantly change, although the governmental logic in relation to the healthcare system remains consistent. This resonates with the nature of emerging economies, whereby organizations need to be adaptive when operating in their institutional environments (Meyer \& Peng, 2016). Thus, foreign hospitals 
need to respond to regulatory changes in a rapid manner, specifically by conforming to new regulatory requirements while responding to institutional (governmental) logics. Table 3 lists the key healthcare policy documents, issued by the Chinese government, that reflect the regulatory changes aimed at foreign hospitals in China.

--- Insert Table 3 about here --- 
Our analysis reveals that foreign hospitals in China operate as social enterprises to organize hybridity by navigating among three different institutional logics-namely, commercial, social, and governmental logics. Organizations should possess the capability to respond to different institutional logics (Greenwood et al., 2011). As for responding to the commercial logic, foreign hospitals are mainly positioned to provide high-end medical services by focussing on a niche market. An executive director of a foreign hospital explained:

Initially, foreign hospitals mainly serve foreign expatriates, because these patients expect to receive health services similar to those of their home countries. In addition, their health insurances can cover the high costs we charge. In return, we provide high quality healthcare services, and most of our doctors are from abroad or with international experience. (Case B, hospital head)

The notion of high-end medical services (高端医疗) has become popular among wealthy individuals amid the rapid rise of the middle and upper classes in Chinese society. In comparison to domestic public hospitals, foreign ones are generally associated with high quality services in exchange for high costs, especially in regard to the calibre of their healthcare professionals and to shorter waiting times. Meanwhile, foreign hospitals also respond to the social logic; the nature of hybrid organizing combines both commercial and social forms at their core. Over time, the foreign hospitals' target patients shift from foreign expatriates to very wealthy domestic individuals. An executive from a healthcare association articulated:

Because there are long waiting times in public hospitals, patients may choose to attend foreign ones when their illnesses are common and they are able to afford the treatment. In most of these cases, patients have to pay for the healthcare services out 
of their pockets, because their basic health insurance plans do not cover them. Nevertheless, foreign hospitals may offer a friendly atmosphere, because the doctors and nurses there are not subjected to the high work pressures found in public hospitals. (Case C, department director)

Importantly, foreign hospitals also indirectly respond to the governmental logic of ensuring equitable access to healthcare services in relation to achieving social welfare. Those patients who can afford to pay more for healthcare services and to see doctors at foreign hospitals reduce the numbers of patients who turn to public ones. This, in turn, may alleviate the burden of those healthcare professionals who work in large public hospitals. In so doing, it may contribute to the transformation of the Chinese healthcare system by achieving both social welfare and market efficiency.

Furthermore, our analysis shows that foreign hospitals further embrace the social logic by actively participating in local communities, especially in terms of performing charity work or voluntary activities. Because the perceptions of foreign hospitals are linked to high cost and high quality, the general patient population will not turn to them. Voluntary engagement activities offer the opportunity to experience the services offered by foreign hospitals for the general public. A senior manager from a foreign hospital explained the rationale:

We aim to let people explore and feel the difference and how we can offer healthcare services differently. Through voluntary activities, we could also educate the local community in the concept of living healthy. If we can live healthy and monitor our health on a regular basis, we may significantly reduce the chance of getting ill or becoming sick. We hope to spread this concept and build a healthy China and a healthy people. (Case A, hospital head) 
This narrative reflects the social logic that drives foreign hospitals to enact these noncommercial activities for the benefit of the community. Furthermore, such community work helps to spread the concept of a healthy lifestyle. The juxtaposition of high-end healthcare services with local community outreach through charity work highlights the inclusive approach adopted by some foreign hospitals. Thus, we argue that foreign hospitals as social enterprises can organize hybridity dynamically such that they can respond to both the commercial and social logics prescribed by hybrid organizations, and to governmental logic when they enter into Chinese market. This inclusive approach and its associated behaviors play a significant role in fostering the Chinese healthcare system reform. The United Nations Sustainable Goal 3 fosters the notion that individual wellbeing and healthcare should favor the prevention of illnesses, instead of their cure. Thus, the activities of foreign hospitals are conducive to moving society at large towards a UN sustainable goal.

Our analysis indicates that the act of organizing hybridity carried out by social enterprises when entering a foreign market necessitates a dynamic approach in developing organizational responses to institutional complexity. Besides the regulatory restrictions, as Cases A and B show, there is the need to learn the local practices and institutional norms. However, when it is possible to set up wholly-owned foreign enterprises, foreign hospitals may set up their own subsidiary as illuminated in Cases C and D.

In the most recent phase, even while regulatory changes continue to open up the healthcare market, foreign hospitals may prefer to use collaborative partnerships in entering the Chinese healthcare sector. Our analysis reflects the nature of emerging economies being one of continuous institutional change and transformation. As such, hybridity needs to be dynamic and flexible, and not static, to ensure its sustainability.

--- Insert Figure 1 about here --- 
In Figure 1, we present five cases, along a trajectory of longitudinal change, of the entry mode choices for foreign hospitals, in accordance with regulatory change and institutional complexity. As Figure 1 illuminates, Chinese healthcare policy evolved along a developmental trajectory from restriction towards an opening up of the sector in favor of foreign hospitals. Multiple government-related agencies were involved in designing and implementing the healthcare policy. Table 3 shows the detailed health policy documents with issued time and government authority as well as the key aspects in relation to foreign healthcare service providers. In the early phase (1989-2000), China's healthcare system can be described as a closed shop. The development phase (2001-2013) was coined to describe a gradual opening of China's healthcare system for foreign hospitals. In 2011 the National Development and Reform Committee announced that the status of foreign-funded medical institutions should change from "restricted categories" to "allowed categories". This was a landmark change in healthcare policy, generating significant implications for foreign hospitals. Cases C and D were founded as wholly foreign-owned hospitals during this phase. The transformation phase (2014-2017) is characterized by a further opening up of the Chinese healthcare market. Despite the possibility to open wholly-owned hospitals, Case E show that, due to the complexity and dynamic of the market, foreign hospitals may still choose collaborative partnerships as the preferred entry mode choice.

\section{Collaborative partnerships as an entry mode choice}

The cases show that collaborative partnerships are a salient entry mode choice for foreign hospitals in China over time. The dynamics of institutional development and institutional voids found in emerging economies require those enterprises that intend to enter and operate 
there to adopt cost effective approaches, such as the use of intermediaries or partnerships to mitigate their risk exposure. A senior manager from a foreign hospital said:

We have to keep in mind that China is still a transitional economy. That means that things are not perfect and can change unexpectedly. Although it allows to set up wholly foreign-owned hospitals; foreign hospitals still prefer to collaborate with good local partners. Different types of partners may work for different projects. Importantly, working with local partners can significantly help us to better understand China's specific healthcare challenges, so that we can better serve the Chinese people and community. (Case E, department manager)

Our analysis shows that different Chinese partners-including real estate developers, stateowned enterprises (SOEs), and Chinese public hospitals - may actively collaborate with foreign hospitals. Choosing the appropriate partners may significantly affect the progression and eventual outcome of the establishment of foreign hospitals in China. A senior executive from a Chinese non-public healthcare association stated:

The most recent foreign hospital projects have set up collaborations with strategic partners. Specifically, foreign hospitals want to leverage local resources, while local organizations want to use foreign healthcare resources. The success or failure of those collaborations hinges on the achievement of mutual benefits and gains for all stakeholders. (Research director, Chinese non-public healthcare association)

This narrative manifests that the generation of mutual interests for both actors involved a collaborative partnership requiring reciprocal relationships to initiate, develop, and sustain it. Such an approach resonates with the importance of building relationships in international collaborations that are aimed at innovation; this is particularly the case for multinational 
enterprises entering the Chinese market (Collinson \& Liu, 2017). A senior healthcare professional from a Chinese public hospital explained:

The main reason we'd like to set up collaborations with foreign hospitals is that we are eager to upgrade our capabilities through the mechanism of people exchange and learning opportunities. Enhancing the capability of Chinese hospitals, in particular by cultivating and training local hospital staff, is the key. (HR manager)

Such upgrading of capabilities may also contribute to the healthcare system reform agenda driven by the Chinese government. However, learning from partners also requires the commitment of resources, time, and patience. A Chinese healthcare professional working in foreign hospitals shared:

Healthcare is a profession. It takes time to learn the skills and knowledge, most of which is tacit knowledge. I think we need to adopt a long-term orientation and commitment to work with foreign doctors and foreign hospitals. It cannot happen overnight. Like the automotive industry, it took almost three decades for Chinese car manufacturing firms to become globally competitive. As for healthcare services providers, we need individual development, organizational support, and also institutional preparedness. (Case B, medical doctor)

This narrative highlights the importance, for Chinese hospitals in particular and the Chinese healthcare system in general, of collaborating with foreign hospitals. It may also support the regulatory change that shifted foreign hospitals from the FDI "restricted" list to "allowed" categories, thus further opening up the Chinese healthcare market. Collaboration may offer significant opportunities for domestic Chinese hospitals to learn and develop, preparing them to compete with their foreign counterparts. 
Furthermore, previous research on the automotive industry demonstrated the benefits linked to setting up joint ventures to cultivate the domestic industry, which saw market access exchanged for technology (Alon, Fetscherin, \& Sardy, 2008; Sun, Mellahi, \& Thun, 2010). The spill-over effects and recursive learning by Chinese domestic firms contributed to the upgrading of their capabilities (Herrigel, Wittke, \& Voskamp, 2013; Zhao \& Anand, 2009). The competitiveness of Chinese companies on the global landscape has been tested in their endeavours to globalize (Liu, Öberg et al., 2018).

In summary, we have provided an overview of the three institutional logics and of the mechanisms that underpin foreign hospital responses to institutional logics. As presented in Table 4, our findings indicate that foreign hospitals respond to governmental, commercial, and social logics through various manifestations hinging on different mechanisms. The response about governmental logic in the entry mode choice of foreign hospitals expands upon the existing understanding that sees the act of hybrid organization performed by social enterprises as concerning only the combination and management of commercial and social forms (Battilana \& Lee, 2014). Our findings reveal that governmental logic is an important institutional logic to which foreign hospitals need to respond dynamically by following an evolving approach.

--- Insert Table 4 about here ---

\section{Discussion}

\section{Theoretical contribution}

Our research makes three contributions to the growing body of research on the internationalization of social enterprises: (1) it identifies collaborative partnerships as a choice of entry mode made by foreign hospitals, understood as hybrid organizations, to adapt to the institutional dynamics of emerging markets; (2) our research uncovers the mechanisms 
deployed by foreign hospitals as hybrid organizations in response to institutional logics; (3) it demonstrates the role played by the government and its interactions with the healthcare service delivery partners in the form of collaborative partnerships aimed at fostering healthcare system reforms.

First, our research indicates that foreign hospitals, characterized as social enterprises, need to organize hybridity in a dynamic way when they enter China. Our findings support previous research that used institutional theory and highlights the important influence of institutional logics on social enterprises in emerging economies (Battilana \& Lee, 2014). Our findings advance the literature on the internationalization of social enterprises (Chmelik et al., 2016; Yang \& $\mathrm{Wu}, 2015)$ by demonstrating that collaborative partnerships are their preferred choice of entry mode when they are faced with institutional dynamics. By articulating the contextual characteristics of institutional dynamics and regulatory changes in China, we contribute to a nuanced understanding of the role played by the government and organizational responses to institutional complexity.

We also articulate the conditions that enable foreign hospitals to act as social enterprises by juxtaposing the social enterprise and entry mode choice literature. Foreign hospitals in China can generate social value for the local healthcare sector, which is the determinant factor for social enterprises (Stephan et al., 2016; Zahra et al., 2009). China's healthcare system reforms and the quest for the delivery of high quality healthcare services place the Chinese government under intense pressure to open up the healthcare service market. Thus, foreign hospitals need to possess the resources and capabilities to capture market opportunities by choosing the entry mode most appropriate for the Chinese market. The institutional dynamics and uncertainties, found in our cases, require foreign hospitals to choose appropriate partners with which to set up collaborative partnerships suited to navigate through the institutional complexity. 
Second, existing research has acknowledged the importance of two salient institutional logics_commercial and social—in affecting social enterprises to manage hybridity (Battilana \& Dorado, 2010; Randøy, Strøm, \& Mersland, 2015) and organizational responses to institutional logics (Pache \& Santos, 2013). Particularly, in emerging economies governments foster institutional changes (Xing et al., 2018) and wield great authority and power in regard to resource allocation (Armanios, Eesley, Li, \& Eisenhardt, 2017). Thus, a more enhanced and contextualized understanding of the distinctive mechanisms adopted by social enterprises in emerging markets is required. Our results highlight the dynamics required to organize hybridity, and the complexity of the institutional logics; a collaborative entry mode is required that offers encompassing services and that complements the role played by foreign hospitals in facilitating their responses to institutional logics. Thus, our results highlight the dynamics and complexities of the institutional logics involved in the entry mode choices of foreign hospitals in China.

In addition, our findings remain particularly salient for foreign hospitals in China because they involve the creation of social value in the presence of changing regulatory frameworks. Previous research showed that the setting up of wholly foreign-owned, for-profit enterprises in China is the preferred entry mode choice when institutional environment allows (Puck et al., 2009). However, our research demonstrates that the complexity of institutional dynamics in emerging economies requires adaptive responses from social enterprises. This also resonates with a previous study that highlighted the challenges faced by social enterprises in China (Wang, Alon, \& Kimble, 2015). Hybrid organizations, as our analysis of the entry mode choice of foreign hospitals illustrates, need to not only combine commercial and social forms (Battilana \& Lee, 2014), but also to respond dynamically to governmental logic.

Third, our research makes a contribution to the literature on health systems in transitional economies (Kyratsis et al., 2017) and on the role played by the government and by its 
interactions with multiple actors. The existing research on health systems, which has tended to focus on the healthcare sectors found in western contexts (Battilana \& Casciaro, 2012; Reay et al., 2006), has failed to uncover the interactions between healthcare service providers and governments. Our conceptualization of hospitals as hybrid organizations and the analysis of entry mode choice of foreign hospitals fill this important gap. Our findings support the use of collaborative partnerships to foster health system reforms by fulfilling multiple institutional logics. In the process of health system reforms, foreign hospitals can take over the roles of social enterprises as hybrid organizations, thus going beyond the commonly acknowledged dual mission linked to the social and commercial logics. Thus, creating social value and responding to the social logic constitutes the critical criterion for social enterprises. In regard to the foreign hospitals' interaction with the Chinese government, our findings might be generalizable beyond social enterprises and hybrid organizations, because, in China, the government largely retains the power to control and allocate critical resources and to legitimize entrepreneurial activities through institutional forces. Importantly, foreign hospitals may contribute to health system reforms by collaborating with local partners to upgrade their capabilities of delivering health services. In so doing, they would corroborate the governmental logic of achieving equitable access to health services.

\section{Policy and managerial implications}

This study has several implications for policymakers, healthcare professionals, and foreign hospitals. Foreign hospitals operating in emerging economies should pay close attention to institutional dynamics. Our research highlights that foreign hospitals may play an important role in contributing to the upgrade in capability of emerging economies to deliver health services. Collaborative partnerships may strongly affect health system reform in emerging economies, as illustrated by our analysis. When an emerging economy undergoes a health system reform, foreign hospitals can actively shape the process by contributing their 
knowledge, expertise, and experience and, in the process, benefit from the resulting institutional transformation. Such private-public collaborative partnerships have important implications for creating value and addressing societal and economic grand challenges (Quelin, Kivleniece, \& Lazzarini, 2017).

As for policy implications, our research indicates that attempts by governments to collaborate with foreign hospitals can be a key component of their overall strategies aimed at transforming their health system. The focus on encouraging collaborative partnerships with foreign hospitals is unique to the Chinese governmental approach to fostering health system reform. Other emerging economies may emulate this collaborative approach by designing and implementing policy initiatives aimed at attracting foreign hospitals.

The recent collaborative partnerships undertaken by the UK's BMI Healthcare and IHG Healthcare Group in China illuminated the market potential and enthusiasm of foreign health service providers. Learning how to collaborate with Chinese partners from past experiences is the key for their successful entry to and operation in the host country. Thus, choosing collaborative partnerships as an entry mode can assist them in navigating through governmental, commercial, and social logics. Because hospitals are always part of a sensitive sector that is highly regulated, our findings may offer some insights to business organizations and policymakers who operate within other highly regulated industries.

Although our analysis focusses on foreign hospitals in China, our findings may be generalizable to other emerging economies - particularly to those with highly regulated pertinent industries in which foreign companies have a preference for a collaborative market entry mode. Our study may also shed revealing light on policy making and implementation, especially in regard to refining policy initiatives to reform health systems and cultivate an atmosphere conducive to attracting foreign hospitals as strategic partners. 


\section{Limitations and future research directions}

Our study has several limitations that await further scholarly inquiry. First, we only examined the entry mode choice of foreign hospitals in China through qualitative analysis. Second, our focal point lay in the collaborative partnerships between foreign hospitals and other actors without using a system-level approach to examine the Chinese heath system. Third, we focussed on the organizational-level analysis without paying attention to the micro-level constructs and processes.

Several fruitful research directions could build on our initial attempt to address the internationalization of social enterprises via collaborative partnerships as an entry mode choice in emerging economies. First, future research could adopt a comparative perspective that involves social and multinational enterprises. Prior research described the distinctive characteristics and strategies of the entry modes of multinational enterprises (Ahsan \& Musteen, 2011). A comparative approach could examine variations across sectors and it would complement our understanding of entry mode choice by investigating the case of social enterprises. For instance, the development of the automotive sector (Alon et al., 2008; Nam, 2011) and of the solar energy industry (Liu, 2017) benefitted from collaborative partnerships with foreign partners. Second, our research focusses mainly on the foreign hospitals' responses to institutional logics in terms of dynamically managing hybridity and utilizing collaborative partnerships. A multitude of actors are involved in the interactions required to foster the health system reform. Future work incorporating other actorsespecially different types of Chinese healthcare service providers-could provide additional insights into collaborative partnerships, both in general and in the specific context of health system reform. Third, by examining the role played by foreign hospitals in fostering health system reforms, we extend the previous work on public-private collaborative partnerships (Xing et al., 2018). However, collaborative partnerships need to seek, establish, and sustain 
relationships with partners appropriate for the achievement of favorable performance outcomes (Collinson \& Liu, 2017; Liu, Lattemann, Xing, \& Dorawa, 2018). A microfoundational perspective is critical to advance international management research (Verbeke \& Calma, 2017). The psychological micro-foundation and human side factors of collaborative partnership (Liu, Sarala, Xing, \& Cooper, 2017), such as resilience (Liu, 2018), may especially generate revealing insights for future scholarly inquiry on the internationalization of social enterprises.

\section{Conclusion}

This article conceptualizes foreign hospitals as social enterprises that balance their social mission with their business success to organize hybridity. We investigate how non-Chinese hospitals respond to three different institutional logics-governmental, commercial, and social-when they enter into China as part of their internationalization processes. In particular, we show that, to enter China, foreign hospitals favor collaborative partnerships; this is in contrast to for-profit enterprises, which favor wholly-owned subsidiaries as their entry mode. Furthermore, our study suggests that understanding the role played by the government and by its relationships with other actors is important to advance research on the internationalization of social enterprises in emerging economies. Our exploratory study offers an attempt to elucidate the complex interplay between foreign hospitals as social enterprises in organizing hybridity and other actors, and serves as a departure point for further theoretical refinement and empirical validation. 


\section{References}

Ahsan, M., \& Musteen, M. (2011). Multinational enterprises' entry mode strategies and uncertainty: A review and extension. International Journal of Management Reviews, 13(4): 376-392.

Almandoz, J. (2014). Founding teams as carriers of competing logics: When institutional forces predict banks' risk exposure. Administrative Science Quarterly, 59(3): 442-473.

Alon, I., Fetscherin, M., \& Sardy, M. (2008). Geely motors: A Chinese automaker enters international markets. International Journal of Chinese Culture and Management, 1(4): 489-498.

André, K., Cho, C. H., \& Laine, M. (2017). Reference points for measuring social performance: Case study of a social business venture. Journal of Business Venturing, Available online 26 December 2017.

Armanios, D. E., Eesley, C. E., Li, J., \& Eisenhardt, K. M. (2017). How entrepreneurs leverage institutional intermediaries in emerging economies to acquire public resources. Strategic Management Journal, 38(7): 1373-1390.

Barbieri, E., Huang, M., Pi, S., \& Tassinari, M. (2017). Restructuring the production of medicines: An investigation on the pharmaceutical sector in China and the role of mergers and acquisitions. International Journal of Environmental Research and Public Health, 14(10): 1179-1200.

Battilana, J., \& Casciaro, T. (2012). Change agents, networks, and institutions: A contingency theory of organizational change. Academy of Management Journal, 55(2): 381-398.

Battilana, J., \& Dorado, S. (2010). Building sustainable hybrid organizations: The case of commercial microfinance organizations. Academy of Management Journal, 53(6): 1419-1440.

Battilana, J., Gilmartin, M., Sengul, M., Pache, A.-C., \& Alexander, J. A. (2010). Leadership competencies for implementing planned organizational change. The Leadership Quarterly, 21(3): 422-438.

Battilana, J., \& Lee, M. 2014. Advancing research on hybrid organizing-Insights from the study of social enterprises. The Academy of Management Annals, 8(1): 397-441.

Battilana, J., Sengul, M., Pache, A.-C., \& Model, J. (2015). Harnessing productive tensions in hybrid organizations: The case of work integration social enterprises. Academy of Management Journal, 58(6): 1658-1685. 
Beamish, P. W., \& Lupton, N. C. (2009). Managing joint ventures. Academy of Management Perspectives, 23(2): 75-94.

Besharov, M. L., \& Smith, W. K. (2014). Multiple institutional logics in organizations: Explaining their varied nature and implications. Academy of Management Review, 39(3): 364-381.

Brouthers, K. D., \& Hennart, J.-F. (2007). Boundaries of the firm: Insights from international entry mode research. Journal of Management, 33(3): 395-425.

Chandra, Y. (2017). A time-based process model of international entrepreneurial opportunity evaluation. Journal of International Business Studies, 48(4): 423-451.

China Daily. (2017). Private hospitals rise on back of FDI.

http://www.chinadaily.com.cn/business/2017-10/09/content_33012993.htm (Accessed 30 January 2018).

Chmelik, E., Musteen, M., \& Ahsan, M. (2016). Measures of performance in the context of international social ventures: An exploratory study. Journal of Social Entrepreneurship, 7(1): 74-100.

Choi, N., \& Majumdar, S. (2014). Social entrepreneurship as an essentially contested concept: Opening a new avenue for systematic future research. Journal of Business Venturing, 29(3): 363-376.

Cobb, J. A., Wry, T., \& Zhao, E. Y. (2016). Funding financial inclusion: Institutional logics and the contextual contingency of funding for microfinance organizations. Academy of Management Journal, 59(6): 2103-2131.

Collinson, S. C., \& Liu, Y. (2017). Recombination for innovation: Performance outcomes from international partnerships in China. $R \& D$ Management, Special Issue Paper, 25 September 2018. https://doi.org/10.1111/radm.12293 (Accessed 25 October 2018)

Cornelissen, J. P. (2017). Preserving theoretical divergence in management research: Why the explanatory potential of qualitative research should be harnessed rather than suppressed. Journal of Management Studies, 54(3): 368-383. 
Dunn, M. B., \& Jones, C. (2010). Institutional logics and institutional pluralism: The contestation of care and science logics in medical education, 1967-2005. Administrative Science Quarterly, 55(1): 114-149.

Ebrahim, A., Battilana, J., \& Mair, J. (2014). The governance of social enterprises: Mission drift and accountability challenges in hybrid organizations. Research in Organizational Behavior, 34: 81-100.

Eggleston, K. (2012). Health care for 1.3 Billion: An overview of China's health system. Working paper, Stanford University.

Eisenhardt, K. M. (1989). Building theories from case study research. Academy of Management Review, 532-550.

Eisenhardt, K. M., \& Graebner, M. E. (2007). Theory building from cases: Opportunities and challenges. The Academy of Management Journal Archive, 50(1): 25-32.

Estrin, S., Baghdasaryan, D., \& Meyer, K. E. (2009). The impact of institutional and human resource distance on international entry strategies. Journal of Management Studies, 46(7): 1171-1196.

Estrin, S., Mickiewicz, T., \& Stephan, U. (2016). Human capital in social and commercial entrepreneurship. Journal of Business Venturing, 31(4): 449-467.

Freeman III, C. W., \& Boynton, X. L. (2011). Implementing health care reform policies in China: Challenges and opportunities, A Report of the CSIS Freeman Chair in China Studies. Washington: Center for Strategic and International Studies.

Friedland, R., \& Alford, R. R. (1991). Bringing society back in: Symbols, practices and institutional contradictions. In W. W. Powell, \& P. J. DiMaggio (Eds.), The new institutionalism in organizational analysis (pp. 232-266). Chicago: University of Chicago Press.

George, G., Howard-Grenville, J., Joshi, A., \& Tihanyi, L. (2016). Understanding and tackling societal grand challenges through management research. Academy of Management Journal, 59(6): 1880-1895.

Greenwood, R., Raynard, M., Kodeih, F., Micelotta, E. R., \& Lounsbury, M. (2011). Institutional complexity and organizational responses. The Academy of Management Annals, 5(1): 317371. 
Helmig, B., Spraul, K., \& Ingenhoff, D. (2016). Under positive pressure: How stakeholder pressure affects corporate social responsibility implementation. Business \& Society, 55(2): 151-187.

Herrigel, G., Wittke, V., \& Voskamp, U. (2013). The process of Chinese manufacturing upgrading: Transitioning from unilateral to recursive mutual learning relations. Global Strategy Journal, 3(1): 109-125.

Hoskisson, R. E., Wright, M., Filatotchev, I., \& Peng, M. W. (2013). Emerging multinationals from Mid - Range economies: The influence of institutions and factor markets. Journal of Management Studies, 50(7): 1295-1321.

Islam, M. N. (2016). Public health challenges in contemporary China: An interdisciplinary perspective. Heidelberg: Springer-Verlag.

Janssen, F., Fayolle, A., \& Wuilaume, A. (2018). Researching bricolage in social entrepreneurship. Entrepreneurship \& Regional Development, 30(3-4): 450-470.

Kim, W. C., \& Hwang, P. (1992). Global strategy and multinationals' entry mode choice. Journal of International Business Studies, 23(1): 29-53.

Kogut, B., \& Singh, H. (1988). The effect of national culture on the choice of entry mode. Journal of International Business Studies, 19(3): 411-432.

Kulik, C. T., Ryan, S., Harper, S., \& George, G. (2014). Aging populations and management. Academy of Management Journal, 57(4): 929-935.

Kyratsis, Y., Atun, R., Phillips, N., Tracey, P., \& George, G. (2017). Health systems in transition: Professional identity work in the context of shifting institutional logics. Academy of Management Journal, 60(2): 610-641.

Lattemann, C., Fetscherin, M., Alon, I., Li, S., \& Schneider, A. M. (2009). CSR communication intensity in Chinese and Indian multinational companies. Corporate Governance: An International Review, 17(4): 426-442.

Li, S., Angelino, A., Yin, H., \& Spigarelli, F. (2017). Determinants of FDI localization in china: A county-level analysis for the pharmaceutical industry. International Journal of Environmental Research and Public Health, 14(9): 985-1005. 
Li, S., Fetscherin, M., Alon, I., Lattemann, C., \& Yeh, K. (2010). Corporate social responsibility in emerging markets. Management International Review, 50(5): 635-654.

Lin, C.-T., \& Tsai, M.-C. (2010). Location choice for direct foreign investment in new hospitals in China by using ANP and TOPSIS. Quality \& Quantity, 44(2): 375-390.

Littlewood, D., \& Holt, D. (2018). Social entrepreneurship in South Africa: Exploring the influence of environment. Business \& Society, 57(3): 525-561.

Liu, Y. (2017). Born global firms' growth and collaborative entry mode: The role of transnational entrepreneurs. International Marketing Review, 34(1): 46-67.

Liu, Y. (2018). Contextualizing risk and building resilience: Returnees versus local entrepreneurs in China. Applied Psychology: An International Review, Forthcoming.

Liu, Y., Lattemann, C., Xing, Y., \& Dorawa, D. (2018). The emergence of collaborative partnerships between knowledge-intensive business service (KIBS) and product companies: The case of Bremen, Germany. Regional Studies, DOI: 10.1080/00343404.2018.1510178

Liu, Y., \& Meyer, K. E. (2018). Boundary spanners, HRM practices, and reverse knowledge transfer: The case of Chinese cross-border acquisitions. Journal of World Business, Forthcoming (https://doi.org/10.1016/j.jwb.2018.07.007).

Liu, Y., Öberg, C., Tarba, S. Y., \& Xing, Y. (2018). Brand management in Mergers and Acquisitions: Emerging market multinationals venturing into advanced economies. International Marketing Review, 35(5): Forthcoming.

Liu, Y., Sarala, R. M., Xing, Y., \& Cooper, C. L. (2017). Human side of collaborative partnerships: A micro-foundational perspective. Group \& Organization Management, 24(2): 151-162.

Liu, Y., \& Vrontis, D. (2017). Emerging markets firms venturing into advanced economies: The role of context. Thunderbird International Business Review, 59(3): 255-261.

Lönnroth, K., Aung, T., Maung, W., Kluge, H., \& Uplekar, M. (2007). Social franchising of TB care through private GPs in Myanmar: An assessment of treatment results, access, equity and financial protection. Health Policy And Planning, 22(3): 156-166.

Lou, J., Li, B., Yin, W., Kim, J. Y., \& Chan, M. (2016). Deepening health reform in China: Building high-quality and value-based service delivery, China Joint Study Partnership. Washington, 
DC: World Bank Group, World Health Organization, Ministry of Finance, National Health and Family Planning Commission, Ministry of Human Resources and Social Security.

Lumineau, F., \& Oliveira, N. (2018). A pluralistic perspective to overcome major blind spots in research on interorganizational relationships. Academy of Management Annals, https://doi.org/10.5465/annals.2016.0033

Lyles, M. A., \& Salk, J. E. (1996). Knowledge acquisition from foreign parents in international joint ventures: An empirical examination in the Hungarian context. Journal of International Business Studies, 27(5): 877-903.

Mair, J., \& Marti, I. (2006). Social entrepreneurship research: A source of explanation, prediction, and delight. Journal of World Business, 41(1): 36-44.

Mair, J., Mayer, J., \& Lutz, E. (2015). Navigating institutional plurality: Organizational governance in hybrid organizations. Organization Studies, 36(6): 713-739.

Majchrzak, A., Griffith, T. L., Reetz, D. K., \& Alexy, O. (2018). Catalyst organizations as a new organization design for innovation: The case of hyperloop transportation technologies. Academy of Management Discoveries, Published Online:16 Mar 2018: https://doi.org/10.5465/amd.2017.0041

McMullen, J. S., \& Bergman Jr, B. J. (2017). Social entrepreneurship and the development paradox of prosocial motivation: A cautionary tale. Strategic Entrepreneurship Journal, 11(3): 243-270.

McMullen, J. S., \& Warnick, B. J. (2016). Should we require every new venture to be a hybrid organization? Journal of Management Studies, 53(4): 630-662.

Meyer, K. E. (2001). Institutions, transaction costs, and entry mode choice in Eastern Europe. Journal of International Business Studies, 32(2): 357-367.

Meyer, K. E., Estrin, S., Bhaumik, S. K., \& Peng, M. W. (2009). Institutions, resources, and entry strategies in emerging economies. Strategic Management Journal, 30(1): 61-80.

Meyer, K. E., Mudambi, R., \& Narula, R. (2011). Multinational enterprises and local contexts: The opportunities and challenges of multiple embeddedness. Journal of Management Studies, 48(2): 235-252. 
Meyer, K. E., \& Peng, M. W. (2016). Theoretical foundations of emerging economy business research. Journal of International Business Studies, 47(1): 3-22.

Musteen, M., Datta, D. K., \& Herrmann, P. (2009). Ownership structure and CEO compensation: Implications for the choice of foreign market entry modes. Journal of International Business Studies, 40(2): 321-338.

Nam, K.-M. (2011). Learning through the international joint venture: Lessons from the experience of China's automotive sector. Industrial and Corporate Change, 20(3): 855-907.

Nigam, A., \& Ocasio, W. (2010). Event attention, environmental sensemaking, and change in institutional logics: An inductive analysis of the effects of public attention to Clinton's health care reform initiative. Organization Science, 21(4): 823-841.

Nyssens, M. (2006). Social enterprise: At the crossroads of market, public policies and civil society. Abingdon: Routledge.

Pache, A.-C., \& Santos, F. (2013). Inside the hybrid organization: Selective coupling as a response to conflicting institutional logics. Academy of Management Journal, 56(4): 972-1001.

Pahnke, E. C., Katila, R., \& Eisenhardt, K. M. (2015). Who takes you to the dance? How partners' institutional logics influence innovation in young firms. Administrative Science Quarterly, 60(4): 596-633.

Puck, J. F., Holtbrügge, D., \& Mohr, A. T. (2009). Beyond entry mode choice: Explaining the conversion of joint ventures into wholly owned subsidiaries in the People's Republic of China. Journal of International Business Studies, 40(3): 388-404.

Quelin, B. V., Kivleniece, I., \& Lazzarini, S. (2017). Public-private collaboration, hybridity and social value: Towards new theoretical perspectives. Journal of Management Studies, 54(6): 764-792.

Randøy, T., Strøm, R. Ø., \& Mersland, R. (2015). The impact of entrepreneur - CEOs in microfinance institutions: A global survey. Entrepreneurship Theory and Practice, 39(4): 927-953. 
Reay, T., Golden-Biddle, K., \& Germann, K. (2006). Legitimizing a new role: Small wins and microprocesses of change. Academy of Management Journal, 49(5): 977-998.

Reay, T., \& Hinings, C. B. (2005). The recomposition of an organizational field: Health care in Alberta. Organization Studies, 26(3): 351-384.

Reay, T., \& Hinings, C. R. (2009). Managing the rivalry of competing institutional logics. Organization Studies, 30(6): 629-652.

Reay, T., \& Jones, C. (2016). Qualitatively capturing institutional logics. Strategic Organization, 14(4): 441-454.

Roundy, P. T., \& Bonnal, M. (2017). The singularity of social entrepreneurship: Untangling its uniqueness and market function. The Journal of Entrepreneurship, 26(2): 137-162.

Santos, F., Pache, A.-C., \& Birkholz, C. (2015). Making hybrids work: Aligning business models and organizational design for social enterprises. California Management Review, 57(3): 36-58.

Sengupta, S., Sahay, A., \& Croce, F. (2017). Conceptualizing social entrepreneurship in the context of emerging economies: An integrative review of past research from BRIICS. International Entrepreneurship and Management Journal, November 2017: 1-33. Doi: 10.1007/s11365$017-0483-2$

Smith, W. K., \& Besharov, M. L. (2017). Bowing before dual gods: How structured flexibility sustains organizational hybridity. Administrative Science Quarterly, first published 19 December, DOI: https://doi.org/10.1177/0001839217750826

Smith, W. K., Gonin, M., \& Besharov, M. L. (2013). Managing social-business tensions: A review and research agenda for social enterprise. Business Ethics Quarterly, 23(3): 407-442.

Stephan, U., Patterson, M., Kelly, C., \& Mair, J. (2016). Organizations driving positive social change: A review and an integrative framework of change processes. Journal of Management, 42(5): $1250-1281$.

Stephan, U., Uhlaner, L. M., \& Stride, C. (2015). Institutions and social entrepreneurship: The role of institutional voids, institutional support, and institutional configurations. Journal of International Business Studies, 46(3): 308-331. 
Sun, P., Mellahi, K., \& Thun, E. (2010). The dynamic value of MNE political embeddedness: The case of the Chinese automobile industry. Journal of International Business Studies, 41(7): $1161-1182$

Süssmuth-Dyckerhoff, C., \& Then, F. (2017). China's healthcare reform status and outlook. In L. R. Burns, \& G. G. Liu (Eds.), China's healthcare system and reform (pp. 137-149). Cambridge: Cambridge University Press.

Thornton, P. H. (2004). Markets from culture: Institutional logics and organizational decisions in higher education publishing. Stanford, CA: Stanford University Press.

Thornton, P. H., Ocasio, W., \& Lounsbury, M. (2012). The institutional logics perspective: A new approach to culture, structure, and process. Oxford: Oxford University Press.

United Nations. (2015). Transforming our world: the 2030 Agenda for Sustainable Development. https://sustainabledevelopment.un.org/post2015/transformingourworld (Accessed 6 September 2017).

Verbeke, A., \& Calma, A. (2017). Footnotes on JIBS 1970-2016. Journal of International Business Studies, 48(9): 1037-1044.

Waldorff, S. B., \& Greenwood, R. (2011). The dynamics of community translation: Danish healthcare centres. In C. Marquis, M. Lounsbury, \& R. Greenwood (Eds.), Communities and organizations, Vol. 33 (pp. 113-142). Bingley: Emerald Group Publishing.

Wang, H., Alon, I., \& Kimble, C. (2015). Dialogue in the dark: Shedding light on the development of social enterprises in China. Global Business and Organizational Excellence, 34(4): 60-69.

Weill Cornell Medicine. (2017). Weill Cornell Medicine to help plan international hospital in Shanghai, China. https://news.weill.cornell.edu/news/2017/02/weill-cornell-medicine-to-helpplan-international-hospital-in-shanghai-china (Accessed 30 January 2018).

White, L., Currie, G., \& Lockett, A. (2014). The enactment of plural leadership in a health and social care network: The influence of institutional context. The Leadership Quarterly, 25(4): 730745.

Wry, T., Lounsbury, M., \& Jennings, P. D. (2014). Hybrid vigor: Securing venture capital by spanning categories in nanotechnology. Academy of Management Journal, 57(5): 1309-1333. 
Xing, Y., \& Liu, Y. (2015). Poetry and leadership in light of ambiguity and logic of appropriateness. Management and Organization Review, 1-31.

Xing, Y., Liu, Y., \& Cooper, C. L. (2018). Local government as institutional entrepreneur:

Collaborative partnerships in fostering regional entrepreneurship. British Journal of Management, 29(4): 670-690. DOI: https://doi.org/10.1111/1467-8551.12282

Xing, Y., \& Starik, M. (2017). Taoist leadership and employee green behaviour: A cultural and philosophical microfoundation of sustainability. Journal of Organizational Behavior, 38(9): $1302-1319$.

Yang, Y.-k., \& Wu, S.-1. (2015). An exploratory study to understand the internationalization strategies of social enterprises. Journal of Social Entrepreneurship, 6(1): 31-41.

Yin, R. K. (2009). Case study research: Design and methods. Sage Publications.

Zahra, S. A., Gedajlovic, E., Neubaum, D. O., \& Shulman, J. M. (2009). A typology of social entrepreneurs: Motives, search processes and ethical challenges. Journal of Business Venturing, 24(5): 519-532.

Zahra, S. A., \& Wright, M. (2016). Understanding the social role of entrepreneurship. Journal of Management Studies, 53(4): 610-629.

Zhao, Z. J., \& Anand, J. (2009). A multilevel perspective on knowledge transfer: Evidence from the Chinese automotive industry. Strategic Management Journal, 30(9): 959-983. 
Table 1. Primary interviewees

\begin{tabular}{llcc}
\hline Informants & Foreign hospitals & $\begin{array}{c}\text { Number of } \\
\text { interviews }\end{array}$ & Roles and positions \\
\hline $\begin{array}{l}\text { Hospital } \\
\text { professionals }\end{array}$ & 8 & $\begin{array}{c}\text { medical doctors, department directors, HR } \\
\text { managers, hospital heads }\end{array}$ \\
\hline $\begin{array}{l}\text { Healthcare } \\
\text { associations }\end{array}$ & $\begin{array}{l}\text { Health service } \\
\text { providers }\end{array}$ & 5 & $\begin{array}{c}\text { executives, department managers, } \\
\text { research director, analyst, research fellow }\end{array}$ \\
& $\begin{array}{l}\text { Medical } \\
\text { Association }\end{array}$ & 3 & \\
\hline Government officials & $\begin{array}{l}\text { Beijing Municipal } \\
\text { Health Bureau }\end{array}$ & 6 & directors, deputy directors, department \\
& heads, project managers \\
& Bureau Health & 7 & \\
\hline
\end{tabular}


Table 2. An overview of the five cases in this study

\begin{tabular}{lllll}
\hline & $\begin{array}{l}\text { Type of entry } \\
\text { mode }\end{array}$ & $\begin{array}{l}\text { Founding } \\
\text { year }\end{array}$ & $\begin{array}{l}\text { Targeted patient } \\
\text { groups }\end{array}$ & $\begin{array}{l}\text { Country } \\
\text { of origin }\end{array}$ \\
\hline Case A & $\begin{array}{l}\text { Collaborative } \\
\text { partnership }\end{array}$ & 1997 & Foreign expats & USA \\
\hline Case B & $\begin{array}{l}\text { Collaborative } \\
\text { partnership }\end{array}$ & 2004 & $\begin{array}{l}\text { High-end patients, } \\
\text { esp. gynaecology } \\
\text { (pregnant women) }\end{array}$ & USA \\
\hline Case C & $\begin{array}{l}\text { Wholly foreign- } \\
\text { owned enterprise }\end{array}$ & 2012 & $\begin{array}{l}\text { Patients from the } \\
\text { region of Taiwan }\end{array}$ & Taiwan \\
\hline Case D & $\begin{array}{l}\text { Wholly foreign- } \\
\text { owned enterprise }\end{array}$ & 2013 & $\begin{array}{l}\text { High end patients, } \\
\text { esp. ophthalmology } \\
\text { (eyes) }\end{array}$ & $\begin{array}{l}\text { Hong } \\
\text { Kong }\end{array}$ \\
\hline Case E & $\begin{array}{l}\text { Collaborative } \\
\text { partnership }\end{array}$ & 2014 & $\begin{array}{l}\text { Non-high-end } \\
\text { patients }\end{array}$ & USA \\
\hline
\end{tabular}


Table 3. Health policy and regulatory changes

\begin{tabular}{|c|c|c|}
\hline Health policy documents & $\begin{array}{l}\text { Document issue time, } \\
\text { government authority }\end{array}$ & Key aspects toward foreign healthcare service providers \\
\hline $\begin{array}{l}\text { Regulations on the operation } \\
\text { of hospitals and clinics for } \\
\text { foreigners and overseas } \\
\text { Chinese and the practice of } \\
\text { medicine in China by foreign } \\
\text { doctors }\end{array}$ & $\begin{array}{l}\text { 1989.2, Ministry of } \\
\text { Health, and Ministry of } \\
\text { International Economics } \\
\text { and Trade }\end{array}$ & $\begin{array}{l}\text { - } \text { Foreign doctors can practice medicine in China } \\
\text { - } \quad \text { Foreign-funded medical institutions in China have been initially permitted } \\
\text { - } \quad \text { This regulation promoted the development of foreign-funded hospitals in China }\end{array}$ \\
\hline $\begin{array}{l}\text { Provisional measures for the } \\
\text { administration of foreign } \\
\text { doctors practicing medicine in } \\
\text { China for short terms }\end{array}$ & $\begin{array}{l}\text { 1992.09, Ministry of } \\
\text { Health, PR. China }\end{array}$ & $\begin{array}{l}\text { - China began to allow foreign doctors to provide clinical diagnosis and treatment } \\
\text { activities } \\
\text { - The duration of foreign doctors' stay should not exceed one year }\end{array}$ \\
\hline $\begin{array}{l}\text { Supplementary provisions on } \\
\text { the establishment of foreign- } \\
\text { invested hospitals }\end{array}$ & $\begin{array}{l}\text { 1997.04, Ministry of } \\
\text { International Economics } \\
\text { and Trade }\end{array}$ & $\begin{array}{l}\text { - The supplementary provisions include the nature of foreign-funded medical } \\
\text { institutions, the proportion of equity, business scope, business deadline and personnel } \\
\text { appointment and dismissal } \\
\text { - The joint-venture Chinese holding ratio should not be less than 50\%; under special } \\
\text { circumstances, the joint venture Chinese holding ratio shall not be less than 30\% } \\
\text { - Wholly foreign-owned medical institutions are not allowed }\end{array}$ \\
\hline
\end{tabular}




\section{Interim measures for the} administration of Sino-foreign joint ventures and cooperative medical institutions

\section{5, Ministry of}

Health, and Ministry of

International Economics and Trade
- Defines the standard of foreign investment in the hospital and stipulates the threshold for foreign investment in China's medical industry

- The total investment should not be less than 20 million yuan, but the maximum shareholding ratio is up to $70 \%$, and the joint venture term does not exceed 20 years

- Chinese-foreign joint ventures and cooperative medical institutions should not set up branch offices (Article 17)

- Foreign medical institutions must undergo the joint examination and approval by the Ministry of Health and the Ministry of Commerce to officially set up, and shall not establish branch offices

$\begin{array}{ll}\text { Guiding opinions on hospital } & \text { 2005.3, Ministry of } \\ \text { comprehensive reform } & \text { Health }\end{array}$

- Offers guiding opinions on deepening reform of urban medical service system

- A small number of regions have been at the forefront of the promulgation of relevant guiding opinions on the reform of the hospital system and the diversification of property rights

- Some measures have benefitted foreign investment in hospitals in China
2010.12, Ministry of

Health, Ministry of

Commerce
- China has liberalized the restrictions on Hong Kong, Macao and Taiwan-funded medical institutions

establishment of sole

proprietorship hospitals on the

Mainland and Interim

administrative rules on the

establishment of wholly

foreign-owned hospitals on the

Mainland by Taiwanese

investors 
Catalogue of industries for guiding foreign investment in China
2011.12, National

Development and Reform

Committee
- From January 30, 2012, foreign-funded medical institutions change from being restricted categories to allowed categories

- The threshold for foreign investment in China's medical service has been greatly reduced

\begin{tabular}{ll}
\hline $\begin{array}{l}\text { Opinions on promoting the } \\
\text { accelerated development of }\end{array}$ & $\begin{array}{l}\text { 2014.1, National Health } \\
\text { and Family Planning }\end{array}$ \\
private medical institutions & Committee
\end{tabular}

accelerated private medical institutions
- Further relaxation of the scope of overseas-funded, wholly-owned hospitals on the Mainland and extension of the geographical coverage of service providers in Hong Kong, Macao, and Taiwan to establish wholly-owned hospitals on the Mainland to cities above the prefecture level in accordance with the principle of gradual liberalization and controllable risks

- Other qualified overseas capital can set up wholly-owned medical institutions in specific regions, such as the China (Shanghai) Free Trade Zone
- Foreign investors are allowed to set up wholly foreign-owned hospitals in the pilot areas through new establishment or mergers and acquisitions and Family Planning Committee, and Ministry of Commerce

- The examination and approval authority of foreign medical organizations for shortterm practice in China were decentralized to municipal-level health and family planning administrative departments

- The examination and approval of for-profit medical institutions was changed from pre-approval to post-approval in business registration 


Opinions on encouraging
social forces to provide multi-
layered and diverse healthcare
services

2017.5, State Council

services
- Attract foreign investors to come to China to establish high-level medical institutions through joint ventures and cooperation, and actively introduce professional medical personnel, advanced medical technologies, modern management experience, and novel business models

- Develop medical and health service trade zones, implement the "One Belt and One Road" strategy, strengthen international cooperation and promotion of the health industry

- Support all kinds of business entities, including private medical institutions, to carry out medical services and health services trade for the international market and highincome earners to create an internationally competitive medical and health service trading organization and a healthy tourism destination 
Table 4. Mechanisms for foreign hospitals responding to institutional logics

\begin{tabular}{|c|c|c|c|}
\hline $\begin{array}{l}\text { Foreign } \\
\text { hospital }\end{array}$ & Governmental logic & Commercial logic & Social logic \\
\hline \multirow[t]{2}{*}{$\begin{array}{l}\text { Organizing } \\
\text { hybridity } \\
\text { dynamically }\end{array}$} & $\begin{array}{l}\text { Facilitating equitable access } \\
\text { to healthcare and } \\
\text { sustainable development }\end{array}$ & $\begin{array}{l}\text { Delivering high-end healthcare } \\
\text { services by charging premium rates }\end{array}$ & $\begin{array}{l}\text { Generating social value and } \\
\text { engaging with local communities } \\
\text { by charitable or voluntary activities }\end{array}$ \\
\hline & $\begin{array}{l}\text { Contributing to Chinese } \\
\text { health system reform }\end{array}$ & $\begin{array}{l}\text { Targeting niche markets; e.g., foreign } \\
\text { expatriates or highly wealthy } \\
\text { individuals }\end{array}$ & $\begin{array}{l}\text { Advocating the concept of "Living } \\
\text { a healthy life and wellbeing" }\end{array}$ \\
\hline \multirow{2}{*}{$\begin{array}{l}\text { Utilizing } \\
\text { collaborative } \\
\text { partnerships } \\
\text { as an entry } \\
\text { mode }\end{array}$} & $\begin{array}{l}\text { Adapting to government } \\
\text { policy and regulatory } \\
\text { changes }\end{array}$ & $\begin{array}{l}\text { Choosing different types of partners } \\
\text { and organizations for different projects }\end{array}$ & $\begin{array}{l}\text { Addressing sophisticated healthcare } \\
\text { issues collaboratively with local } \\
\text { public hospitals }\end{array}$ \\
\hline & $\begin{array}{l}\text { Upgrading the capability of } \\
\text { Chinese healthcare service } \\
\text { providers }\end{array}$ & $\begin{array}{l}\text { Mitigating risk exposure through } \\
\text { partnerships }\end{array}$ & $\begin{array}{l}\text { Creating social value via the } \\
\text { exchange of healthcare service } \\
\text { knowledge and experience with } \\
\text { Chinese partners }\end{array}$ \\
\hline
\end{tabular}


Figure 1. Chinese healthcare policy development and entry mode choice of foreign hospitals

Healthcare policy development

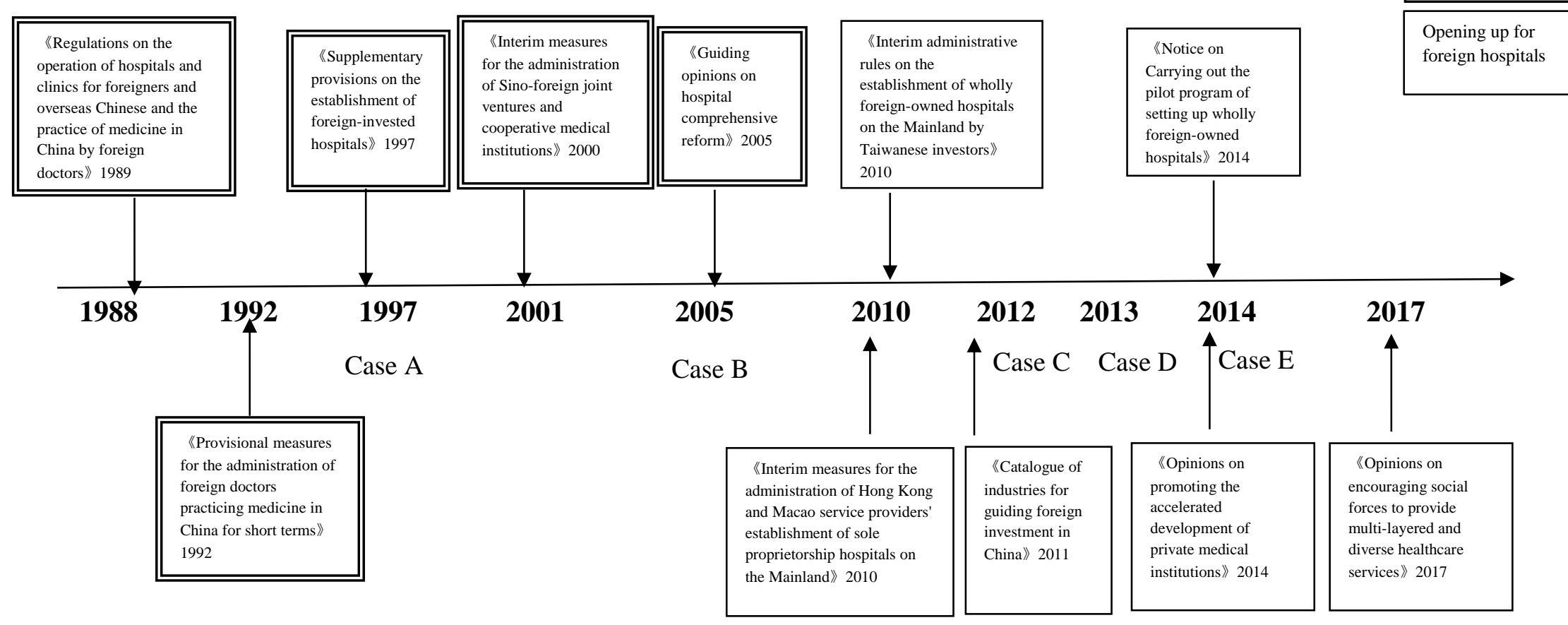

